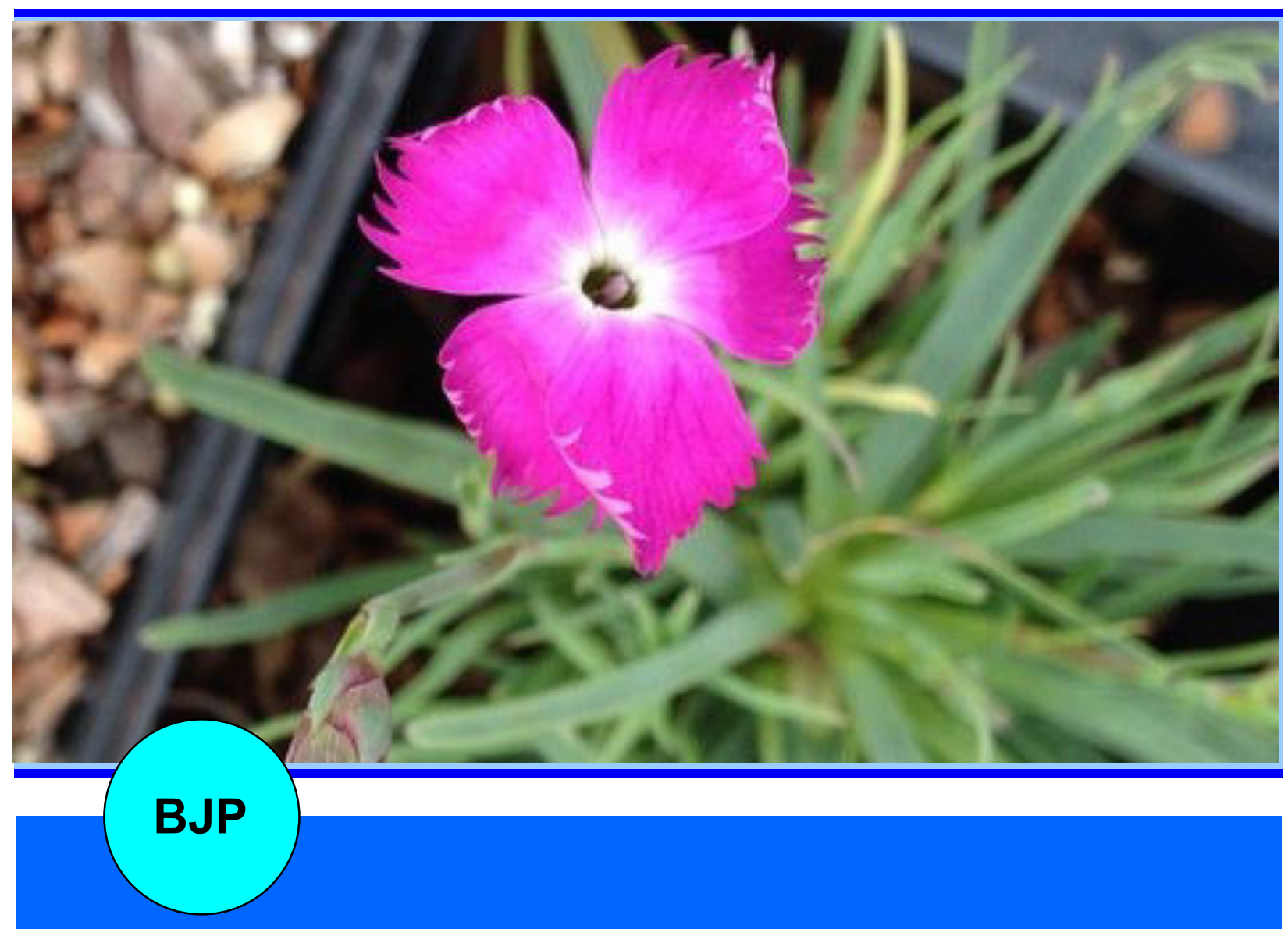

Bangladesh Journal of Pharmacology

Research Article

Antimicrobial and cytotoxic potential of Dianthus basuticus used in Basotho traditional practice 


\title{
Antimicrobial and cytotoxic potential of Dianthus basuticus used in Basotho traditional practice
}

\author{
S. Q. Njabulo Lamula and A. O. Tom Ashafa
}

Phytomedicine and Phytopharmacology Research Group, Department of Plant Sciences, University of the Free State Qwaqwa Campus. Private Bag X 13 Puthaditjhaba 9866, South Africa.

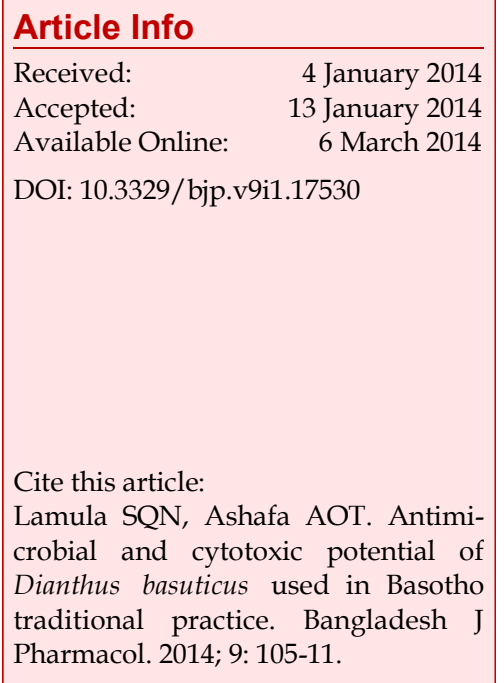

\begin{abstract}
The antimicrobial potential of Dianthus basuticus extracts were investigated using 96 wells microplate against selected bacteria and fungi strains while the cytotoxicity was assessed using brine shrimp lethality assay. All the extracts except water inhibited both Gram negative and Gram positive bacteria with the minimal inhibitory concentrations (MIC) ranging from 1.56 to $6.25 \mathrm{mg}$ / $\mathrm{mL}$, except Escherichia coli, Proteus vulgaris and Shigella sonnei that were inhibited at $12.50 \mathrm{mg} / \mathrm{mL}$ by dichloromethane extract. Similarly, the acetone and ethanol extracts suppressed the growth of Candida rugosa, C. neoformans, C. albicans and Trichophyton mucoides with the MIC ranging from 1.56 to 6.25 $\mathrm{mg} / \mathrm{mL}$. The ethyl acetate fraction of the hydro-alcohol extract inhibited most of the bacteria and fungi at $0.78 \mathrm{mg} / \mathrm{mL}$. The cytotoxicity assay results showed that both hydro-alcohol and ethanol extracts had toxic effect on the brine shrimp larvae with the $\mathrm{LC}_{50}$ values of 17.29 and $59.42 \mu \mathrm{g} / \mathrm{mL}$ respectively, while the phytochemical analysis revealed the presence of alkaloids, tannins, saponins and cardiac glycosides. The results confirms moderate to potent antimicrobial activity of D. basuticus.
\end{abstract}

\section{Introduction}

Infectious diseases account for a large proportion of mortality rate in most developing countries of the world while resistance to antimicrobial agents has become a major global public health problem (Okello et al., 2010; Naz and Bano, 2013). The continuous evolution of bacterial resistance to currently available antibiotics has necessitated the search for novel and effective antimicrobial compounds (Yakubu et al., 2012). Globally, plant extracts are investigated for their all inclusive antimicrobial activities; yet, the therapeutic potentials of many of these plants have not been scientifically evaluated and validated (Fagbemi et al., 2009; Havagiray et al., 2004).

Cancer continues to represent the largest cause of mortality in the world claiming up to six million lives per annum (Fawzy et al., 2013). The strategy for cancer prevention today is chemoprevention which involves the use of both synthetic and natural agents individually or in synergy to block the development of cancer in humans (Fawzy et al., 2013). Plants in the forms of vegetables, herbs and spices that are used in traditional medicines have been generally been accepted as one of the main sources of cancer chemopreventive drug bioprospecting (Fawzy et al., 2013; Sarkar and Mandal, 2011).

In South Africa, majority of the populations relies on herbal medicines and traditional practices but the most are those people who come from poor communities that do not have an access to the Western remedies (van Wyk, 2011). Medicinal plants such as the Dianthus species in the family Caryophyllaceae has been found to posses medicinal properties, species such as Dianthus basuticus, D. basuticus var. basuticus, D. caespitosus 
subsps pectinatus and D. thunbergii which have been shown to be effective for certain ailments, such as fertility and philtre (Aremu et al., 2012). Dianthus species are evergreen soft-wooded perennials with bright pink flowers and deeply fringed. It is native to the Drakensberg Mountains in South Africa and also found in KwaZulu Natal, Lesotho, Cape Province, Free State and Northern Provinces (grassland and rocks) (Raimondo et al., 2009).

D. basuticus has been used as a immune modulator, for flatulency, to increase fertility of bulls and the roots chewed as charm to retain a loved one's affection (Malviya et al., 2011). The roots are scraped and mixed with water to produce lather which young girls initiates wash themselves to enhance their beauty, as medicine for chest pains and to relieve apprehension and fear and also used in mumps. Despite the immense reliance of this tribe on these species, there is little or no information in literature validating the use of the plant in the Basotho traditional medicine. Because of the folk stories around the Dianthus species having medicinal activities, we decided to investigate this species scientifically in order to lend scientific credence to the folkloric claims. So this paper presents the minimum inhibitory concentrations (MIC) of the D. basuticus extracts and the preliminary cytotoxicity testing of the plant using the brine shrimp (Artemia salina nauplii) lethality test.

\section{Materials and Methods}

Plant collection and identification: The plant material was collected in January 2012 using two approaches. One, material was purchased from herbal vendors in Phuthaditjhaba, and two, the species was collected from the field around QwaQwa in the Golden Gate Mountains ( $28^{\circ} 28^{\prime \prime} 111^{\prime} \mathrm{S}$ and $28^{\circ} 48^{\prime \prime} 314^{\prime} \mathrm{E}$; altitude $11950 \mathrm{~m})$, The park extends between the towns of Clarens $(20 \mathrm{~km})$ and Phuthaditjhaba $(40 \mathrm{~km})$ on the R712 Provincial road. It is characterized by summer rainfall, temperate summers and cold winters. Summers are cool with the possibility of thunderstorms while winters are cold with occasional snow. The collector took cognizance of species abundance and collected in such a way that the existence of species is not threatened. Proper identification and authentication was done at the Bews Herbariun of the University of Kwazulu Natal, Pietermarisburg Campus by Dr CJ Potgieter. Herbarium voucher with reference number (LamMed/01/2013/Qhb) was prepared and deposited at the UFS-Qwaqwa campus herbarium.

Preparation of the extract: $30 \mathrm{~g}$ each of the dried powdered materials was extracted in acetone, ethanol, hydroalcohol, dichloromethane and distilled water respective -ly, with shaking on Labcon platform shaker (Laboratory Consumables, PTY, Durban, South Africa) for 24 hours. All extract were filtered using Whatman No. 1 filter paper. The filtrates from acetone, ethanol and dichloromethane were concentrated under reduces pressure $45^{\circ} \mathrm{C}$ using rotary (Cole Parmer SB 1100, Shangai, China) evaporator. The filtrates from hydro-alcohol and water extracts were placed in the water bath at $45^{\circ} \mathrm{C}$ and evaporated to dryness and the yields were calculated weight of the crude extract in relation to the initial starting materials. The yields were $0.1,0.5,2.2,0.1$, and $1.9 \mathrm{~g}$ for acetone, ethanol, hydro alcohol, dichloromethane and distilled water, respectively.

Phytochemical screening: Phytochemical constituents of D. basuticus plant material was determined in the aqueous extract and powdered plant material by adopting standard methods as described by Harborne (1973), Trease and Evans (1989), Sofowora (1993) and Edeoga et al. (2005).

Test for alkaloids: Briefly, $0.5 \mathrm{~g}$ of the powdered plant material was stirred in $5 \mathrm{~mL}$ of $1 \%$ aqueous hydrochloric acid, heated on a water bath and filtered. Then, $1 \mathrm{~mL}$ of the filtrate was treated with few drops of Mayer's reagent and a second portion was treated same way only with Dragendroff's reagent. Turbidity of precipitation with either of those reagents was taken as preliminary evidence for the presence of alkaloids in the extract.

Test for tannins: In the test for tannins, $0.5 \mathrm{~g}$ of dried powdered sample was boiled in $20 \mathrm{~mL}$ of water in a test tube and filtered. Few drops of $0.1 \%$ ferric chloride was added and observed for brownish green or a blue black colouration as indication of tannins.

Test for phlobatannins: In brief, aqueous extract was boiled with $1 \%$ aqueous hydrochloric acid and observed for deposition of red precipitate as an indication of phlobatannins.

Test for saponin: Approximately $2 \mathrm{~g}$ of powdered material was boiled in $20 \mathrm{~mL}$ of distilled water in a water bath and filtered. Next, $10 \mathrm{~mL}$ of the filtrate was mixed with $5 \mathrm{~mL}$ of distilled water and shaken vigorously and observed for a stable persistent froth. The frothing was mixed with 3 drops of olive oil and shaken vigorously again and then observed for the formation of emulsion as an indication of saponin.

Test for flavonoids: A portion of the powdered material was heated with $10 \mathrm{~mL}$ of ethyl acetate over a steam bath for $3 \mathrm{~min}$. The mixture was then filtered and $4 \mathrm{~mL}$ of the filtrate was shaken with $1 \mathrm{~mL}$ of dilute ammonia solution. Development of yellow colouration is an indication of the presence of flavonoids.

Test for steroids: In this test, $2 \mathrm{~mL}$ of acetic anhydride was added to $0.5 \mathrm{~g}$ of ethanolic extract with $2 \mathrm{~mL}$ concentrated $\mathrm{H} 2 \mathrm{SO} 4$. The colour change from violet to blue or green is an indication of steroids.

Test for terpenoids (Salkowski's test): In brief, $5 \mathrm{~mL}$ of extract was mixed with $2 \mathrm{~mL}$ chloroform and $3 \mathrm{~mL}$ $\mathrm{H}_{2} \mathrm{SO}_{4}$ was carefully added to form a layer. A reddish 
brown coloration of the interface was an indication of terpenoids.

Test for cardiac glycosides (keller-kiliani test): In this test, 5 $\mathrm{mL}$ of the extract was treated with $2 \mathrm{~mL}$ of glacial acetic acid containing one drop of ferric chloride solution. This was underplayed with $1 \mathrm{~mL}$ of concentrated $\mathrm{H}_{2} \mathrm{SO}_{4}$. A brown ring of the interface indicates a deoxysugar characteristic of cardenolides. A violet ring may appear below the brown ring, while in the acetic acid layer, a greenish ring may form just gradually throughout the thin layer.

Cytotoxicity (brine shrimp lethality test): The brine shrimp lethality test using brine shrimp was carried out by adopting the standard procedure as described by Meyer et al. (1982). For both extract samples, sae water was added to get a concentration of $1,000 \mu \mathrm{g} / \mathrm{mL}$ of the extract used as a stock solution. Different concentrations $(20-100 \mu \mathrm{g} / \mathrm{mL})$ of both extracts were prepared from the stock solution by serial dilution technique in different vials. Ten nauplii were transferred into each vial using Pasteur pipettes and were not given food because hatched brine shrimp can survive for up to 48 hours without food as they still feed on their yolk-sac. The control vials were prepared using saline water only and the experiment was replicated three times. After 24 hours of incubation, the vials were examined, the numbers of survivors in each vial were counted and percentages of deaths were calculated. Larvae were considered dead if they did not exhibit any observable movement during several seconds of observation. The extract is regarded as non-toxic if its $\mathrm{LC}_{50}$ is greater than $100 \mu \mathrm{g} / \mathrm{mL}$ in the brine shrimp lethality assay (Meyer et al., 1982). The mean mortality percentage and $\mathrm{LC}_{50}$ (lethal concentration for $50 \%$ of the population) were determined using statistical analysis and the graph of Logarithm of concentration against percent lethality.

Test organisms: Four Gram positive and six Gram negative bacteria were tested in this study. Gram positive namely, Bacillus pumilis ATCC 14884, Staphylococcus aureus ATCC 6538, S. aureus OK2a and S. aureus OK2b and Gram negative namely, Actinetobacter calcaoceuticus anitratus CSIR, Escherichia coli ATCC 8739, Proteus vulgaris CSIR 0030, Enterobacter faecalis KZN, S. sonnei ATCC 29930, and S. flexneri KZN. Four fungal species namely, Candida rugosa, C. neoformans, C. albicans and Trichophyton mucoides were also tested. These organisms were obtained from the Department of Biochemistry and Microbiology, University of Fort Hare, South Africa and maintained on nutrient agar and potato dextrose agar plates, then revived for bioassay by subculturing in fresh nutrient broth (Middlebrook broth 7H9) for 24 hours before use.

Antimicrobial activity assays: The MIC values of acetone, ethanol, dichloromethane, hydro-alcohol and water extracts on the organisms were determined using micro -plate dilution method according to Ellof, 1998.
Bacterial strains were cultured overnight for 24 hours in autoclaved nutrient broth (Middlebrook broth 7H9) and were adjusted to a final density of $15 \mathrm{~Hz}$. This was used to inoculate 96-well microtitre plates containing the different dilutions of extracts (12.50 to $0.08 \mathrm{mg} / \mathrm{mL})$ under aseptic condition. The plates were incubated under aerobic conditions at $37^{\circ} \mathrm{C}$ for 24 hours. $40 \mu \mathrm{L}$ of $0.2 \mathrm{mg} / \mathrm{mL}$ p-iodonitrotetrazolium (INT) (97\% purity, Sigma, South Africa) solution was used as a bacterial growth indicator, this was added to each well and incubated for $30 \mathrm{~min}$ at $37^{\circ} \mathrm{C}$. The change of the colour from being colourless to a red coloured product was taken as biological activities of organisms. Each treatment was performed in double and a complete suppression of growth at a specific concentration of an extract was required for it to be declared active (Sindambiwe et al., 1999; Mathekga et al., 2000). Pure distilled water and sample free solvents were use as controls. The same procedure was repeated for the antifungal testing only that the plates were incubated at $25^{\circ} \mathrm{C}$ unlike $37^{\circ} \mathrm{C}$ for the bacteria

Partitioning and fractionation: Three extracts (acetone, ethanol and hydro-alcohol) were active against tested bacteria and fungi during initial antibacterial testing. Therefore, crude hydro-alcohol extract was chosen for the partitioning. $48.5 \mathrm{~g}$ crude extract was subjected to mass fraction using hexane, ethyl acetate and petroleum ether. The assay was carried out according to the method previously described by Sharhidi-Bonjar (2004), as adopted by Okei et al. (2009). $1500 \mathrm{~mL}$ of hexane yielded $0.3 \mathrm{~g}, 1,050 \mathrm{~mL}$ of ethyl acetate yielded $0.9 \mathrm{~g}$, $900 \mathrm{~mL}$ of petroleum ether yielded $17.4 \mathrm{~g}$. All fractions were brought to dryness and used to prepare stock solution of $50 \mathrm{mg} / \mathrm{mL}$ before the antimicrobial assays.

\section{Results}

The qualitative phytochemical screening of D. basuticus extract revealed the presence of alkaloids, tannins, sapo -nins and cardiac glycosides. phlobatannin, flavonoids, steroids and terpenoids were not detected (Table I).

The cytotoxic effects of $D$. basuticus hydro-alcohol and ethanol extracts are presented in Table II. The hydroalcohol extract at $40 \mu \mathrm{g} / \mathrm{mL}$ had $90 \%$ mortality rate on brine shrimp larvae compared to $0.0 \%$ recorded for ethanol extract at the same concentration. Overall, the hydro-alcohol extract exerted the most toxic effect exhibiting $\mathrm{LC}_{50}$ value of $17.3 \mathrm{ug} / \mathrm{mL}$ compare to 59.4 $\mu \mathrm{g} / \mathrm{mL}$ obtained from the ethanol extract. This is an indication that the combination of water and ethanol was able to extract more of the antitumor compounds in the plant. According to Meyer et al. (1982), if the $\mathrm{LC}_{50}$ of any drug including plant extract is less than $100 \mu \mathrm{g} / \mathrm{mL}$ such drug is considered cytotoxic. Conclusively, the two extracts tested in this study could be regarded as toxic to brine shrimp larvae cells based on the $\mathrm{LC}_{50}$ values. 


\begin{tabular}{|ccl|}
\hline \multicolumn{3}{|c|}{ Table I } \\
\hline \multicolumn{3}{|c|}{ Qualitative phytochemical screening of Dianthus } \\
basuticus extracts \\
\hline \multicolumn{3}{|c|}{ Compounds } \\
\hline 1 & Alkaloids & Positive \\
2 & Tannins & Positive \\
3 & Phlobatannins & Negative \\
4 & Saponins & Positive \\
5 & Flavonoids & Negative \\
6 & Steroids & Negative \\
7 & Terpenoids & Negative \\
8 & Cardiac glycosides & Positive \\
\hline
\end{tabular}

Table II

\begin{tabular}{|cccc|}
\hline \multicolumn{4}{|c|}{ Table II } \\
\hline \multicolumn{3}{|c|}{$\begin{array}{c}\text { The cytotoxicity of the Dianthus basuticus } \\
\text { extracts against Artemia salina nauplii }\end{array}$} \\
$\begin{array}{c}\text { Concentra- } \\
\text { tion }(\mu \mathrm{g} / \\
\mathrm{mL})\end{array}$ & $\mathrm{n}$ & \multicolumn{2}{c|}{$\begin{array}{c}\text { Number of dead } \\
\text { (24 hours) }\end{array}$} \\
\cline { 2 - 4 } & $\mathrm{n}$ & $\begin{array}{c}\text { Hydro- } \\
\text { alcohol }\end{array}$ & Ethanol \\
20 & 10 & 7 & 3 \\
40 & 10 & 9 & 0 \\
60 & 10 & 10 & 5 \\
80 & 10 & 10 & 4 \\
100 & 10 & 10 & 10 \\
$\mathrm{LC}_{50}$ & & 17.3 & 59.4 \\
\hline
\end{tabular}

$\mathrm{mg} / \mathrm{mL}$, except $S$. flexneri which was inhibited at 3.1 $\mathrm{mg} / \mathrm{mL}$ and $S$. aureus $\mathrm{OK} 2 \mathrm{a}$ at $1.6 \mathrm{mg} / \mathrm{mL}$, respectively after 24 hours. The water extract was the least active of all the extract in all bacterial strains with the MIC of $12.5 \mathrm{mg} / \mathrm{mL}$ after 24 hours. Generally all the extracts exhibited moderate to potent antibacterial activity against all the tested bacteria in this study, except dichloromethane and water extracts which were less effective against most bacterial strains.

The results of MIC of D. basuticus extracts against Candida rugosa, C. neoformans, C. albicans and Trychophyton mucoides are presented in Table IV. The acetone extract was more active against fungal strains with the MIC ranging from 1.6 to $3.1 \mathrm{mg} / \mathrm{mL}$, except Candida rugosa that was inhibited at $6.3 \mathrm{mg} / \mathrm{mL}$ after 24 hours. The ethanol extract was active at $6.3 \mathrm{mg} / \mathrm{mL}$ while Hydro-alcohol, dichloromethane and water extracts were only active at $12.5 \mathrm{mg} / \mathrm{mL}$ after 24 hours. These results shows that acetone extract was more effective than the other extracts followed by the ethanol extract with hydro alcohol, dichloromethane and water extracts having less effect on the fungal strains in this study.

The ethyl acetate fraction of hydro-alcohol extract exhibited significant activity against all Gram positive and Gram negative bacteria strains tested with the minimal inhibition concentration (MIC) of $0.4 \mathrm{mg} / \mathrm{mL}$, except E. coli ATCC 8739, S. aureus OK2a and S. aureus $\mathrm{OK} 2 \mathrm{~b}$ with the $\mathrm{MIC}$ of 0.8 , and $3.1 \mathrm{mg} / \mathrm{mL}$,

Table III

Antibacterial activity of Dianthus basuticus extracts showing minimal inhibitory concentrations (MIC) against bacterial strains

Bacteria strains
Actinetobacter calcaoceuticus anitratus CSIR
Bacillus pumilis ATCC 14884
Enterobacter faecalis KZN
Escherichia coli ATCC 8739
Proteus vulgaris CSIR 0030
Shigella flexneri KZN
Shigella sonnei ATCC 29930
Staphylococcus aureus ATCC 6538
Staphylococcus aureus OK2a
Staphyolococcus aureus OK2b

The results of MIC of D. basuticus extracts are presented in Table III. The acetone, hydro-alcohol and ethanol extracts were the most active against Gram positive and Gram negative bacteria, inhibiting all strains at MIC 1.6 to $3.1 \mathrm{mg} / \mathrm{mL}$ except E. coli, P. vulgaris and S. sonnei that were both inhibited at $6.3 \mathrm{mg} / \mathrm{mL}$ respectively. The dichloromethane extract was less active against all bacterial strains with the MIC ranging from 6.3 to 12.5

\begin{tabular}{|c|c|c|c|c|c|}
\hline \multicolumn{6}{|c|}{ Extracts (mg/mL) } \\
\hline $\begin{array}{c}\text { Gram } \\
\text { staining }\end{array}$ & Acetone & $\begin{array}{l}\text { Hydro- } \\
\text { alcohol }\end{array}$ & Ethanol & $\begin{array}{l}\text { Dichloro- } \\
\text { methane }\end{array}$ & Water \\
\hline Negative & 3.1 & 6.3 & 1.6 & 6.3 & 12.5 \\
\hline Positive & 3.1 & 1.6 & 1.6 & 6.3 & 12.5 \\
\hline Negative & 1.6 & 1.6 & 3.1 & 6.3 & 12.5 \\
\hline Negative & 6.3 & 6.3 & 6.3 & 12.5 & 12.5 \\
\hline Negative & 6.3 & 6.3 & 6.3 & 12.5 & 12.5 \\
\hline Negative & 3.1 & 6.3 & 1.6 & 3.1 & 12.5 \\
\hline Negative & 3.1 & 6.3 & 6.3 & 12.5 & 12.5 \\
\hline Positive & 3.1 & 3.1 & 1.6 & 6.3 & 12.5 \\
\hline Positive & 1.6 & 6.3 & 3.1 & 1.6 & 12.5 \\
\hline Positive & 3.1 & 3.1 & 3.1 & 6.3 & 12.5 \\
\hline
\end{tabular}

respectively. The hexane fraction also showed appreciable activity against all the Gram negatives and one Gram positive bacteria strain with the MIC of $3.1 \mathrm{mg} /$ $\mathrm{mL}$, except Bacillus pumilis ATCC 14884, S. aureus OK2a and $S$. aureus $\mathrm{OK} 2 \mathrm{~b}$ with the $\mathrm{MIC}$ of $6.3 \mathrm{mg} / \mathrm{ml}$. Petroleum ether fraction was less effective against all the Gram positives and Gram negatives bacteria tested with the MIC of $12.5 \mathrm{mg} / \mathrm{mL}$. 


\begin{tabular}{|c|c|c|c|c|c|c|c|}
\hline \multicolumn{8}{|c|}{ Table IV } \\
\hline \multicolumn{8}{|c|}{$\begin{array}{l}\text { Antifungal activity of Dianthus basuticus extracts and fractions showing minimal inhibitory concentrations } \\
\text { (MIC) }\end{array}$} \\
\hline \multirow[t]{2}{*}{ Fungi strains } & \multicolumn{4}{|c|}{ Extracts $(\mathrm{mg} / \mathrm{mL})$} & \multicolumn{3}{|c|}{ Hydroalcohol fractions $(\mathrm{mg} / \mathrm{mL})$} \\
\hline & $\begin{array}{l}\text { Ace- } \\
\text { tone }\end{array}$ & $\begin{array}{l}\text { Hydroalco- } \\
\text { hol }\end{array}$ & $\begin{array}{l}\text { Dichloro- } \\
\text { methane }\end{array}$ & Water & Hexane & $\begin{array}{l}\text { Ethyl ace- } \\
\text { tate }\end{array}$ & $\begin{array}{c}\text { Petroleum } \\
\text { ether }\end{array}$ \\
\hline Candida rugosa & 6.3 & 12.5 & 12.5 & 12.5 & 3.1 & 3.1 & 12.5 \\
\hline Candida neoformans & 3.1 & 12.5 & 12.5 & 12.5 & 3.1 & 0.8 & 12.5 \\
\hline Candida albicans & 3.1 & 12.5 & 12.5 & 12.5 & 3.1 & 0.8 & 12.5 \\
\hline Trichophyton mucoides & 1.6 & 12.5 & 12.5 & 12.5 & 3.1 & 0.8 & 12.5 \\
\hline \multicolumn{8}{|c|}{ Table V } \\
\hline \multicolumn{8}{|c|}{$\begin{array}{l}\text { Antibacterial activity of fractions from Dianthus basuticus hydro-alcohol extract showing minimal } \\
\text { inhibitory concentrations (MIC) against bacterial strains }\end{array}$} \\
\hline \multirow[t]{2}{*}{ Bacteria strains } & & & Gram staining & \multicolumn{4}{|c|}{ Extracts $(\mathrm{mg} / \mathrm{mL})$} \\
\hline & & & & Ethyl acetate & & Hexane & Petroleum ether \\
\hline \multicolumn{3}{|c|}{ Actinetobacter calcaoceuticus anitratus CSIR } & Negative & 0.4 & & 3.1 & 12.5 \\
\hline \multicolumn{3}{|c|}{ Bacillus pumilis ATCC 14884} & Positive & 0.4 & & 6.3 & 12.5 \\
\hline \multicolumn{3}{|c|}{ Enterobacter faecalis KZN } & Negative & 0.4 & & 3.1 & 12.5 \\
\hline \multicolumn{3}{|c|}{ Escherichia coli ATCC 8739} & Negative & 0.8 & & 3.1 & 12.5 \\
\hline \multicolumn{3}{|c|}{ Proteus vulgaris CSIR 0030} & Negative & 0.4 & & 3.1 & 12.5 \\
\hline \multicolumn{3}{|c|}{ Shigella flexneri KZN } & Negative & 0.4 & & 3.1 & 12.5 \\
\hline \multicolumn{3}{|c|}{ Shigella sonnei ATCC 29930} & Negative & 0.4 & & 3.1 & 12.5 \\
\hline \multicolumn{3}{|c|}{ Staphylococcus aureus ATCC 6538} & Positive & 0.4 & & 3.1 & 12.5 \\
\hline \multicolumn{3}{|c|}{ Staphylococcus aureus OK2a } & Positive & 3.1 & & 6.3 & 12.5 \\
\hline \multicolumn{3}{|c|}{ Staphyolococcus aureus $\mathrm{OK} 2 \mathrm{~b}$} & Positive & 3.1 & & 6.3 & 12.5 \\
\hline
\end{tabular}

Against the four fungal strains, the hexane fraction exhibited appreciable activity with the MIC of $3.1 \mathrm{mg} /$ $\mathrm{mL}$. The ethyl acetate fraction showed a significant activity against all the tested fungi with the MIC of 0.8 $\mathrm{mg} / \mathrm{mL}$, except Candida rugosa with MIC of $3.1 \mathrm{mg} / \mathrm{ml}$. Petroleum ether fraction was also less effective in fungal strains with the MIC of $12.5 \mathrm{mg} / \mathrm{mL}$.

\section{Discussion}

Plants are still being used in many different countries around the world and they are a good source of potent and powerful drugs. There have been scientific articles validating that some of the plants used in Africa can manage most of the diseases and can also heal different injuries depending on their applications and intended purposes of individuals (Okwu and Josiah, 2006). In the last few decades most African countries have seen the need to put more efforts in medicinal plant research field, especial in South Africa, in which the government has decided to officially incorporate herbal remedies as medicine into the health care system (van Wyk, 2011). As medicinal plant drug discovery continues to provide new potent and powerful drugs, it is also important to recognise that it can lead to the development of new drugs which will target diseases that are resistant to current drugs, such as HIV/AIDS, Alzheimer's and pains (Balunas and Kinghorn, 2005).

Many researchers have used MIC as an index for measuring the efficacy of antimicrobial agents (Kabir et al., 2005; Ushimaru et al., 2007; Yakubu et al., 2012). The results from the present study have shown that $D$. basuticus does possesses moderate to potent antimicrobial activity against the tested bacteria and fungi. The acetone and ethanol extracts were more active than the other extracts against all the bacteria and fungi strains tested with the MIC ranging from 1.6 to $6.3 \mathrm{mg} / \mathrm{mL}$. Differences in activity of extracts had been related to the qualitative and quantitative diversity of compounds that was extracted by different solvents (Geyid et al., 2005). Acetone extract a broad range of compounds, thus allowing an effective preliminary screening for bioactive compounds. Other solvents, such as hexane and methanol might extract a wide range of compounds, but acetone will always extract compounds with a wider range of polarities (Eloff, 1998). The ethanol extract exhibited only strong antibacterial activity and moderate activity against fungi strains tested. The hydro-alcohol and water can extract large quantities of materials in the plant, but the least number of compounds comes up in the extracts (Angeh, 2006). This could be the reason why the water extract had the least activity and the possibility that the active phytochemicals in the plant are non polar in nature. 
Although the extracts exhibited varied degree of inhibition, previous reports have attributed this to the type of extracting solvents and the plant material involved (Mabona and van Vuuren, 2013). The acetone ethanol, hydro-alcohol and dichloromethane extracts from the plant were active against Gram positive and Gram negative bacteria with the MIC ranging from 1.6 and $6.3 \mathrm{mg} / \mathrm{mL}$, except E. coli ATCC 8739, P. vulgaris CSIR 0030 and S. sonnei ATCC 29930 with a MIC of 12.5 $\mathrm{mg} / \mathrm{mL}$ by dichloromethane extract. The observed inconsistency in the sensitivity amongst Gram negative and Gram positive bacteria along with the fungal isolates could be ascribed to the anatomical or structural differences between these microorganisms (Ashafa and Umebese, 2012).

As observed from the $\mathrm{LC}_{50}$, the hydro-alcohol extracted most of the toxic compounds with the value of $17.3 \mu \mathrm{g} /$ $\mathrm{mL}$. According to Meyer et al. (1982), if the $\mathrm{LC}_{50}$ value is less than $100 \mu \mathrm{g} / \mathrm{mL}$, the plant is considered cytotoxic. Cytotoxic property of plant material is due to the presence of antitumor compounds, so the strong cytotoxic activity of this plant has made it a candidate for further anticancer exploration using both normal and cancer cell lines.

Recent reports have shown that there is reduction in the discovery of new antimicrobial agents globally, coupled with ever increasing cases of drug resistant to available antimicrobials (Khan et al., 2012; Ashafa, 2013). Some of the bacteria and fungi tested in this study have history of causing different infections and drug resistant have also been documented. Acinetobacter calcaoceticus anitratus has been documented with highly variable degree of virulence causing meningitis, fulminating septicaemia, pulmonary and ophthalmic infections and more, while the Staphylococci, E. coli and Shigella are known to cause food poisoning resulting in nausea, vomiting, diarrhea and dehydration. The importance of investigating the fungicidal activity of plant extracts cannot be over emphasized in the view that the fungal infections are major source of concern throughout the world (Abebe et al., 2003; Yakubu et al., 2012). Candida species are the most common cause of human fungal infections, representing nearly $96 \%$ of all opportunistic mycoses (Pfaller and Diekema, 2007; Ashafa and Umebese, 2012). Up to $2 \%$ of intensive care unit (ICU) patients suffer from invasive candidiasis, the incidence of which shows and alrming increase during the last few decades (Manolakaki et al., 2010). All these organisms were inhibited by the crude ethyl acetate and hexane fractions at MIC ranging from $0.4 \mathrm{mg} / \mathrm{mL}$ to 3.1 $\mathrm{mg} / \mathrm{mL}$. This is an indication that if bioactive compounds are purified from these extracts, the antimicrobial potency will increase and may form a good source of new additions into the realm of available antibiotics.

The brine shrimp lethality test is an in vivo lethality in a simple zoological organism that could be used as a simple tool to guide screening and fractionation of physiological active plant extracts, where one of the simplest biological responses to monitor is lethality, since there is only one criterion; either dead or alive (Pimentel-Montanher et al., 2002; Olorunnisola et al., 2011). In the present study, hydro-alcohol and ethanol whole plant extracts of $D$. basuticus displayed significant lethality against brine shrimp naupli with $\mathrm{LC}_{50}$ of 17.3 and $59.4 \mu \mathrm{g} / \mathrm{mL}$ respectively. There is a general toxicity test agreement that $\mathrm{LC}_{50}$ above $100 \mu \mathrm{g} /$ $\mathrm{mL}$ is non-toxic while that below $100 \mu \mathrm{g} / \mathrm{mL}$ is indicative of toxicity. The significant lethality of the extracts from the root $D$. basuticus is an indication of the presence of potent cytotoxic compounds. The outcome of the present study presents D. basuticus root as a promising natural source of anti-tumor compounds and it deserves further explorations considering the rate of cancer spread in South Africa.

The qualitative phytochemical investigation revealed the presence of alkaloids, tannins, cardiac glycosides and saponins. These compounds have long history of exerting both physiological and medicinal activities (Parekh and Chanda, 2007; Soetan et al., 2006; Khan et al., 2011; Yakubu et al., 2012). These attest its traditional use by Basotho indigenous people in the treatment of various diseases as well as feeding the bulls in order to increase fertility. From the observed antimicrobial activities against bacteria and fungi tested, the cytotoxicity of the plant and the bioactive compounds present in D. basuticus, necessitated further studies to be conducted as the species could be a potential source of useful drugs.

\section{Acknowledgment}

The authors are grateful to the UFS-Qwaqwa Campus Research Committee for funding. We also thank Ms Getrude Mahanke for her support during laboratory works.

\section{References}

Abebe D, Debella A, Urga K. Medicinal plants and other useful plants of Ethopia. Singapore, Camerapix Publishers International, 2003, pp 54-61.

Angeh JE, Huang X, Sattler I, Swan GE, Dahse H, Härtl A. Eloff JN. Antimicrobial and anti-inflammatory activity of four known and one new triterpenoid from Combretum Imberbe (Combretaceae). J Ethnopharmacol. 2007; 110: 56-60.

Aremu AO, Finnie JF, Van Staden J. Potential of South African medicinal plants used as anthelmintics: Their efficacy, safety concerns and reappraisal of current screening methods. South Afri J Bot. 2012; 82: 134-50.

Ashafa AOT, Umebese C: Phytochemical screening, antibacterial and antifungal activity of Garuleum woodii Schinz. root extracts against human pathogenic microbes. J Med Plants Res. 2012; 6: 5513-18.

Ashafa AOT. Medicinal potential of Morella seratta (Lam.) Killick (Myricaceae) root extracts: Biological and pharmacological activities. BMC Complement Altern Med. 2013; 13: 
163.

Balunas MJ, Kinghorn AD. Drug discovery from medicinal plants. Life Sci. 2005; 87: 431-41.

Edeoga HO, Okwu DE, Mbaebie BO. Phytochemical constituents of some Nigerian medicinal plants. Afri J Biotechnol. 2005; 4: 685-88.

Eloff JN. A sensitive and quick microplate method to determine the minimal inhibitory concentration of plant extracts for bacteria. Planta Medica. 1998; 64: 711-13.

Fagbemi JF, Ugoji E, Adenipekun T, Adelowotan O. Evaluation of antimicrobial properties of unripe banana (Musa sapientum L.), lemon grass (Cymbopogun citratus S.) and turmeric (Curcuma longa L.) on pathogens. Afri J Biotechnol. 2009; 8: 1176-82.

Geyid A, Abebe D, Debella A, Makonnen Z, Aberra F, Teka F, Kebede T, Urga K, Yersaw K, Biza T, Mariam BH, Guta M. Screening of some medicinal plants of Ethopia for their antimicrobial properties and chemical profiles. J Ethnopharmacol. 2005; 97: 421-27.

Harbone JB. Phytochemical methods. London, Champman and Hall Ltd., 1973, pp 49-188.

Havagiray R, Ramesh C, Sadhna K. Study of antidiarrhea activity of Calotropis gigantean R.B.R in experimental animals. J Pharmacol Pharm Sci. 2004; 7: 70-75.

Kabir OA, Olukayode O, Chidi EO, Christopher CI, Kehinde EF. Screening the crude extracts of six plants used in South West Nigeria unorthodox medicine for antimethicillin resistant Staphylococcus aureus activity. BMC Comp Altern Med. 2005; 5: 1472-83.

Khan AV, Ahmed QU, Mir MR, Shulka I, Khan AA. Antibacterial efficacy of the seed extracts of Melia azedarach against some hospital isolated human pathogenic bacteria strains. Asian Pac J Tropic Biomed. 2012; 1: 452-55.

Khan FA, Hussain I, Farooq S, Ahmad M, Arif M, Rehman IU. Phytochemical screening of some Pakistanian medicinal plants. Middle-East J Sci Res. 2011; 8: 575-78.

Mabona U, van Vuuren SF. Southern African medicinal plants used to treat skin diseases. South Afri J Bot. 2013; 87: 175-93.

Manolakaki D, Velmahos GC, Kourkoumpetis T, Chang Y, Alam HB, De Moya MM, Mylonakis E. Candida infection and colonization among trauma patients. Virulence 2010; 1: 367-75.

Mathekga ADM, Meyer JJM, Horn MM, Drews SE. An acylated phloroglucinol with antimicrobial properties from Helichrysum caespititum. Phytochemistry 2000; 53: 93-96.

Meyer BN, Ferrigni NR, Putnam JE, Jacobsen LB, Nichols DE,
McLaughlin JL. Brine shrimp: A convenient general bioassay for active plant constituents. Planta Medica. 1982; 45: 31-34.

Naz R, Bano A. Phytochemical screening, anti-oxidants and antimicrobial potential of Lantana camara in different solvents. Asian Pac J Tropic Dis. 2013; 3: 480-86.

Okello SV, Nyunja RO, Natondo GW. Ethnobotanical study of medicinal plants used by Sabaots of Mt. Elgon Kenya. Afri J Tradit Comp Altern Med. 2010; 7: 1-10.

Okwu DE, Josiah C. Evaluation of the chemical composition of two Nigerian medicinal plants. Afri J Biotechnol. 2006; 5: 357 $-61$.

Olorunnisola OS, Bradley G, Afolayan AJ. Anti-oxidant proper -ties and cytotoxicity evaluation of methanolic extract of dried and fresh rhizomes of Tulbaghia violacea. Afri J Pharm Pharmacol. 2011; 5: 2490-97.

Parekh J. Chanda S. In vitro antibacterial activity of the crude methanol extract of Woodfordia fruticosa Kurz. flower (Lythaceae). Braz J Microbiol. 2007; 38: 204-07.

Pfaller MA, Diekema DJ. Epidemiology of invasive candidiasis: A persistent public health problem. Clin Microbiol Rev. 2007; 20: 133-63.

Pimentel-Montanher AB, Pizzolati MG, Costa-Brighente IM: An application of the brine shrimp bioassay for general screening of Brazilian medicinal plants. Acta Farm Bonaerense. 2002; 21: 175-78.

Raimondo D, Von SL, Foden W, Victor JE, Helme NA, Turner RC, Kamundi DA, Manyama PA. Red list of South African plants. Strelitzia 2009; 25: 668.

Sindambiwe JB, Calomme M, Cos P, Totte J, Pieters L, Vlietinck A, Vanden Berghe D. Screening of seven selected Rwandan medicinal plants for antimicrobial and antiviral activites. J Ethnopharmacol. 1999; 65: 71-77.

Soetan KO, Oyekunle MA, Aiyelaagbe O, Fafunso MA. Evaluation of the antimicrobial activity of saponin extract of Sorghum bicolor L. Moench. Afr J Biotechnol. 2006; 5: 2405-07.

Sofowara A. Medicinal plants and traditional medicine in Africa. Nigeria, Spectrum Books Ltd., 1993, p 289.

Trease GE, Evans WC. Pharmacognsy. 11 $1^{\text {th }}$ ed. Canada, Macmillian Publishers, 1989.

Van Wyk BE. The potential of South African plants in the development of new medicinal products. South Afri J Bot. 2011; 77: 812-29.

Yakubu MT, Mostafa M, Ashafa AOT, Afolayan AJ. Antimicrobial activity of the solvent fractions from Bulbine natalensis tuber. Afri J Tradit Comp Altren Med. 2012; 9: 459-64. 